\title{
Assessment of Three Flood Hazard Mapping Methods: A Case Study of Perlis
}

\author{
Nazirah Azizat ${ }^{1}$, and Wan Mohd Sabki Wan Omar ${ }^{1 *}$ \\ ${ }^{1}$ School of Environmental Engineering, Universiti Malaysia Perlis, 02600 Arau, Perlis, Malaysia
}

\begin{abstract}
Flood is a common natural disaster and also affect the all state in Malaysia. Regarding to Drainage and Irrigation Department (DID) in 2007 , about $29,270 \mathrm{~km}^{2}$ or 9 percent of region of the country is prone to flooding. Flood can be such devastating catastrophic which can effected to people, economy and environment. Flood hazard mapping can be used is an important part in flood assessment to define those high risk area prone to flooding. The purposes of this study are to prepare a flood hazard mapping in Perlis and to evaluate flood hazard using frequency ratio, statistical index and Poisson method. The six factors affecting the occurrence of flood including elevation, distance from the drainage network, rainfall, soil texture, geology and erosion were created using ArcGIS 10.1 software. Flood location map in this study has been generated based on flooded area in year 2010 from DID. These parameters and flood location map were analysed to prepare flood hazard mapping in representing the probability of flood area. The results of the analysis were verified using flood location data in year 2013, 2014, 2015. The comparison result showed statistical index method is better in prediction of flood area rather than frequency ratio and Poisson method.
\end{abstract}

\section{Introduction}

Malaysia is located in the equatorial region being high temperature and high humidity throughout the year. The annual average of rainfall over Malaysia is 2500 millilitres and average temperature is $27{ }^{\circ} \mathrm{C}$ [1]. Most flood occurred resulting of cyclical monsoon with Southwest and Northwest monsoons. Heavy rainfall during monsoon season caused adversely impact to inundation area depends on magnitude of flood. Massive flooding have a devastating impact on economy and livelihood of people such as properties damage and loss of life. In Malaysia, an annual cost of loss is about US\$ 274 million and claim lives of people [2]. Therefore, flood prediction is required to determine the area prone to flood and time of flood occurrence in terms of spatial and temporal. Spatial and temporal dynamic of parameter related to flood were analysed in prediction of where and when flood might occur [3].

Most part of floodplain area, flooding occurs repeatedly almost every year. The development of flood model is important to recognize the susceptible areas with different hazard level for decision makers [4]. Flood hazard mapping can be used to identify a prone

* Corresponding author: wansabki@,unimap.edu.my 
area to flood using statistical analysis in GIS software. In the previous study, many methods had been proposed to prepare flood hazard mapping primarily on hydrologic, meteorological and geomorphologic approaches [5]. Basically, method of flood mapping was chosen based on data availability and scale of study area. Selection of suitable method for preparation of flood mapping is very important in determination of accuracy of map.

\section{Materials and Methods}

\subsection{Study area}

Perlis is located in northern part of Peninsular Malaysia (Fig.1). The area of the state also surrounded by Thailand in the north, Kedah in the south and it western coastline is bordered by Straits of Malacca. Located near the equator, Perlis's weather is normally warm and wet throughout the year. It controlled by yearly fluctuation in position of Inter Tropical Convergence Zone resulting distinct rainy periods and prolonged drought period. Perlis was selected as study area on basis of frequent flooding and availability of data.

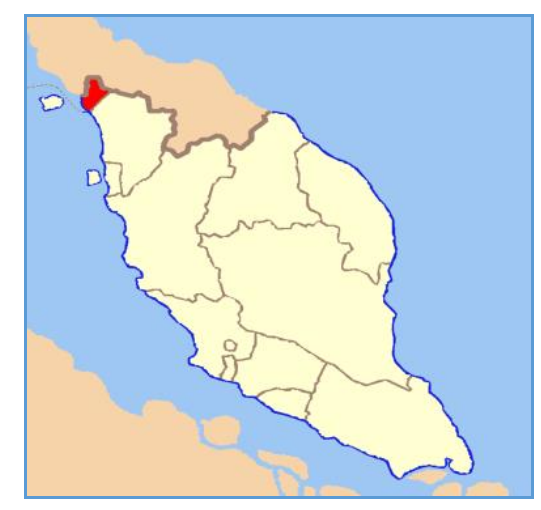

Fig. 1. Location of Study Area.

\subsection{Data collection}

Flood location map was produced in two set. One of flood location map in Perlis was prepared using November 2010 flood extent from DID in producing of flood hazard mapping (Fig. 1). In other hand, point of flood in year 2013, 2014 and 2015 were used in validation of flood mapping (Fig. 2). In analysis of flood hazard mapping, six spatial databases, which consider flood related factor were constructed including elevation, distance from the drainage network, rainfall, soil texture geology and erosion. Each factor was transformed into a grid spatial database by $30 \mathrm{~m} \times 30 \mathrm{~m}$ cell size and grid of Perlis area was constructed by 929 columns and 1744 rows (1, 458, 158, 400 pixels; $1458 \mathrm{~km}^{2}$ ).

A Digital Elevation Model which represent the land surface terrain of the study area was generated from Shuttle Radar Topography Mission (SRTM) which downloaded from United States Geological Survey (USGS) link: https://earthexplorer.usgs.gov/. Distance from drainage networks were calculated using multiple ring buffer in ArcGIS based on annual rainfall. A soil texture, geology and soil erosion were prepared based on field survey by Department of Agriculture. 


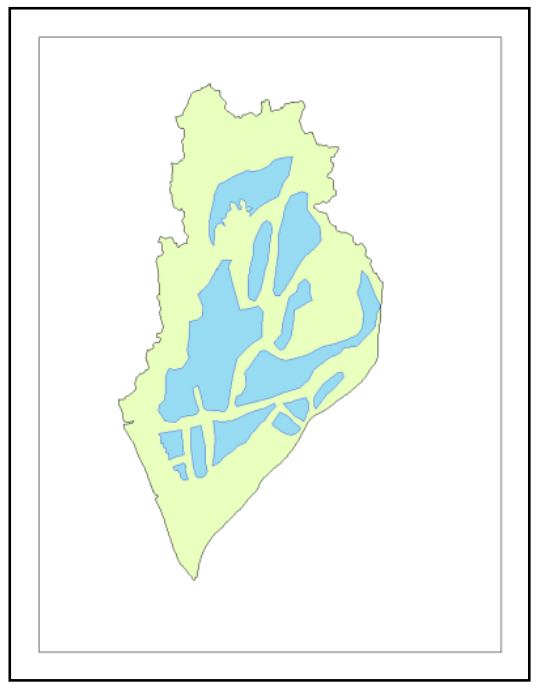

Fig. 2. Flood location map (Analysis).

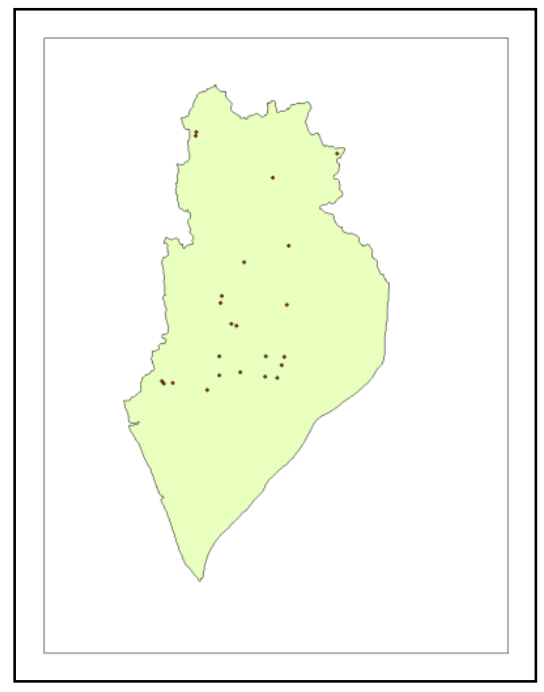

Fig. 3. Flood location map (Validation).

\subsection{Frequency Ratio Model and its Application}

Frequency ratio (FR) approached are based on relationship between location of flood area and each flood related factor to derived correlation between flood location and factors in the study area. Therefore, the frequency ratio of each factor's class were calculated from flood event. Analysis of relation is the ratio of area where flood occurred by total area. If value is greater than 1 , its means a higher correlation and value below than 1 means lower correlation.

Frequency ratio method is used based on assumption that future flood will occurred under similar condition to the past flood using relationships between distribution of flood and each related factor. In calculation of Flood Hazard Index, values of each factor's frequency ratio were summed to produce flood area as in Equation 1:

$$
F r_{i}=\frac{N_{(S i)} / N_{p i x(N i)}}{\sum N_{p i x(S i)} / \sum N_{p i x(N i)}}
$$

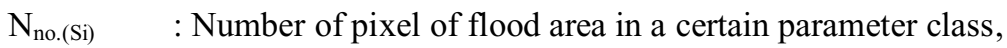

$\mathrm{N}_{\text {pix(Ni) }} \quad$ : Number of pixel in a certain parameter class

$\Sigma \mathrm{N}_{\text {no.(Si) }} \quad$ : Total number pixel of flood area in a certain parameter class

$\Sigma \mathrm{N}_{\text {pix(Ni) }} \quad$ : Total number of pixel in a certain parameter class

To calculate the flood hazard index, each factor's frequency ratio values were summed using overlay tool in ArcGIS. Flood hazard value represents the relative hazard to flood occurrence resulting greater value is higher the hazard to flood and lower value means lower the hazard of flood. In order to facilitate the map, a map of flood hazard zonation is established by dividing flood hazard index into four different flood hazard zones. 


\subsection{Statistical index}

Statistical index (SI) has close similarity to frequency ratio. In this method, weight of every class of each factor is defined as natural logarithm of the flood density in the class divided by total flood density using formula suggested by Van Westen (1997) [6].

$$
\ln W_{i}=\ln \left(\frac{\text { Densclass }}{\text { Densmap }}\right)=\ln \left(\frac{N_{b i l(S i)} / N_{p i x(N i)}}{\sum N_{b i l(S i)} / \sum N_{p i x(N i)}}\right)
$$

Wi value of each attribute was calculated. Flood hazard map was produced by overlaying all the layers. Flood hazard index for statistical index calculation is similar with frequency ratio.

\subsection{Poisson method}

In this method, the probability of flood is 1 . Every class for each factor had been calculated in separately using formulae as below:

$$
P[X]=\frac{\exp (-\theta) * \theta^{X}}{X !}
$$

$\mathrm{X}=1$ (Probability of flood in every class)

$\theta=$ Average between number of flood in class and total number of flood

The calculation flood hazard index also similar with frequency ratio.

\subsection{Validation method}

For validation of flood hazard calculation methods, two basic assumptions are applied. The first assumption states that flood are related to spatial information such as elevation, distance from the drainage network, rainfall, soil texture geology and erosion. On the other hand, the second assumption is future flood will be triggered by specific factor such as rainfall. In this study, both are assumptions were satisfied when the flood occurrence is related to spatial information and triggered by heavy rainfall.

Validation was performed by comparing known flood location with flood hazard map. In this study area, 23 point location of flood in year 2013, 2014 and 2014 had been used in validation of three methods. Point of flood were extracted in every zone hazard of flood mapping to compare of accuracy of three methods.

\section{Results and Discussions}

The relationship between flood occurrence and flood related factors was analysed using frequency ratio, statistical index and Poisson method as shown in Table 1. 
Table 1. Frequency ratio, statistical index and Poisson method of flood occurrence.

\begin{tabular}{|c|c|c|c|c|c|c|}
\hline Factor & Class & $\begin{array}{l}\text { Number of } \\
\text { pixel of flood } \\
\text { in class }\end{array}$ & $\begin{array}{c}\text { Total } \\
\text { Number } \\
\text { pixel in } \\
\text { class }\end{array}$ & FR & SI & Poisson \\
\hline \multirow[t]{8}{*}{ Geology } & $\begin{array}{l}\begin{array}{l}\text { Acid intrusives } \\
\text { (undifferentiated) }\end{array} \\
\end{array}$ & 0 & 5053 & 0.0000 & 0.0000 & 0.0000 \\
\hline & Limestone/marble & 10568 & 137744 & 0.2459 & -1.4026 & 0.0115 \\
\hline & $\begin{array}{l}\text { Phyllite, slate, shale and } \\
\text { sandstone: argillaceous } \\
\text { rock are commonly } \\
\text { carboniferous. Locally } \\
\text { prominent development } \\
\text { of limestone }\end{array}$ & 138608 & 380704 & 1.1671 & 0.1545 & 0.1307 \\
\hline & $\begin{array}{l}\text { Sandstone/metasandstone } \\
\text { with subordinate } \\
\text { siltstone, shale and minor } \\
\text { conglomerate }\end{array}$ & 0 & 219 & 0.0000 & 0.0000 & 0.0000 \\
\hline & $\begin{array}{l}\text { Continental basin } \\
\text { deposits of shale, } \\
\text { sandstone, conglomerate } \\
\text { and minor coal seams }\end{array}$ & 7899 & 66061 & 0.3833 & -0.9589 & 0.0086 \\
\hline & $\begin{array}{l}\text { Clay, silt, sand and gravel } \\
\text { - undifferentiated } \\
\text { (Continental) }\end{array}$ & 39272 & 51845 & 2.4283 & 0.8872 & 0.0413 \\
\hline & Clay and silt (marine) & 87858 & 261201 & 1.0783 & 0.0754 & 0.0876 \\
\hline & Unclassified & 0 & 8240 & 0.0000 & 0.0000 & 0.0000 \\
\hline \multirow[t]{6}{*}{ Erosion } & Moderate & 126273 & 245011 & 1.6521 & 0.5021 & 0.1207 \\
\hline & High & 1369 & 26316 & 0.1668 & -1.7912 & 0.0015 \\
\hline & Moderately High & 92577 & 292765 & 1.0137 & 0.0136 & 0.0918 \\
\hline & Very High & 2294 & 124322 & 0.0592 & -2.8277 & 0.0025 \\
\hline & Low & 61035 & 221091 & 0.8850 & -0.1222 & 0.0627 \\
\hline & Unclassified & 657 & 1562 & 1.3484 & 0.2989 & 0.0007 \\
\hline \multirow[t]{10}{*}{ Soil } & Clay & 14429 & 26395 & 1.7524 & 0.5610 & 0.0156 \\
\hline & Heavy Clay & 11217 & 73597 & 0.4886 & -0.7163 & 0.0122 \\
\hline & Mined Land & 1354 & 6193 & 0.7009 & -0.3554 & 0.0015 \\
\hline & Sandy Clay & 9871 & 99091 & 0.3193 & -1.1415 & 0.0107 \\
\hline & Sandy Clay Loam & 88019 & 330590 & 0.8535 & -0.1584 & 0.0877 \\
\hline & Sandy Loam & 7493 & 18513 & 1.2975 & 0.2604 & 0.0082 \\
\hline & Silty Clay & 146356 & 328542 & 1.4280 & 0.3563 & 0.3077 \\
\hline & Unclassified & 3297 & 12461 & 0.8482 & -0.1647 & 0.0115 \\
\hline & Lake \& Pond & 1512 & 14123 & 0.3432 & -1.0695 & 0.0036 \\
\hline & Unclassifed & 657 & 1562 & 1.3484 & 0.2989 & 0.0017 \\
\hline
\end{tabular}


Table1 (Continued...)

\begin{tabular}{|c|c|c|c|c|c|c|}
\hline Factor & Class & $\begin{array}{l}\text { Number of } \\
\text { pixel of flood } \\
\text { in class }\end{array}$ & $\begin{array}{c}\text { Total } \\
\text { Number } \\
\text { pixel in } \\
\text { class }\end{array}$ & FR & SI & Poisson \\
\hline \multirow[t]{16}{*}{$\begin{array}{l}\text { Annual } \\
\text { rainfall }\end{array}$} & Unclassified & 19 & 123 & 0.4952 & -0.7028 & 0.0000 \\
\hline & 1418 & 19181 & 28197 & 2.1807 & 0.7796 & 0.0206 \\
\hline & 1638 & 21303 & 87690 & 0.7788 & -0.2500 & 0.0228 \\
\hline & 1660 & 37017 & 79147 & 1.4993 & 0.4050 & 0.0390 \\
\hline & 1696 & 18010 & 48859 & 1.1817 & 0.1669 & 0.0194 \\
\hline & 1772 & 22007 & 40408 & 1.7459 & 0.5573 & 0.0236 \\
\hline & 1780 & 1799 & 50475 & 0.1143 & -2.1693 & 0.0020 \\
\hline & 1801 & 9423 & 41641 & 0.7254 & -0.3210 & 0.0102 \\
\hline & 1803 & 35818 & 83990 & 1.3671 & 0.3127 & 0.0378 \\
\hline & 1804 & 28751 & 40845 & 2.2565 & 0.8138 & 0.0306 \\
\hline & 1810 & 37393 & 78848 & 1.5203 & 0.4189 & 0.0394 \\
\hline & 1815 & 4400 & 96231 & 0.1466 & -1.9202 & 0.0048 \\
\hline & 1820 & 13745 & 58907 & 0.7480 & -0.2904 & 0.0149 \\
\hline & 1848 & 9356 & 61200 & 0.4901 & -0.7132 & 0.0102 \\
\hline & 1985 & 25981 & 72686 & 1.1458 & 0.1361 & 0.0277 \\
\hline & 2015 & 0 & 41819 & 0.0000 & 0.0000 & 0.0000 \\
\hline \multirow{5}{*}{$\begin{array}{l}\text { Distance } \\
\text { from } \\
\text { drainage } \\
\text { network }\end{array}$} & 500 & 178031 & 548719 & 1.0400 & 0.0392 & 0.1607 \\
\hline & 1000 & 39596 & 108844 & 1.1661 & 0.1536 & 0.0416 \\
\hline & 1500 & 20213 & 58056 & 1.1160 & 0.1097 & 0.0217 \\
\hline & 2000 & 9550 & 35172 & 0.8703 & -0.1389 & 0.0104 \\
\hline & 10000 & 36895 & 160444 & 0.7371 & -0.3050 & 0.0389 \\
\hline \multirow[t]{5}{*}{ DEM } & $-9-33$ & 206672 & 505740 & 1.3097 & 0.2698 & 0.1808 \\
\hline & $33-98$ & 77106 & 287275 & 0.8602 & -0.1506 & 0.0778 \\
\hline & $98-206$ & 480 & 59284 & 0.0260 & -3.6516 & 0.0005 \\
\hline & $206-354$ & 0 & 38918 & 0.0000 & 0.0000 & 0.0000 \\
\hline & $354-717$ & 0 & 19825 & 0.0000 & 0.0000 & 0.0000 \\
\hline
\end{tabular}

Flood hazard mapping was generated using FR method represent the summation of frequency for each classes of each factor (Fig. 4). Within FR analysis, the relationship between flood occurrence and classes of each factor were obtained. Regarding to the result from Table 1, geology has significant factor which influence of flood based on water behavior on the ground [7]. According to the result of geology, areas with clay, silt, sand and gravel are most influence on flooding in Perlis. Erosion is one of the huge contributors on flood disaster. Erosion is natural process that reshape of land and transporting soil. In the case of soil texture, most of flood occurred in soil types of clay. Rainfall is a main factor in triggering of flood in Perlis. The heavy rainfall makes the river overflow the bank 
river resulting temporarily covers the land by water [4]. The highest annual rainfall showed rainfall is significantly factor, which trigger of flood. Moreover, the areas with frequent flood occurrence were located near to the drainage networks. Urbanization aggravates flooding problem due to the increased runoff and sediment transporting capacity thus causing perturbations to river equilibrium [8]. The result of elevation showed the lower elevation was the most influential class on flooding. Flood hazard mapping was produced based on three methods are shown in Fig. 4, Fig. 4 and Fig. 6.

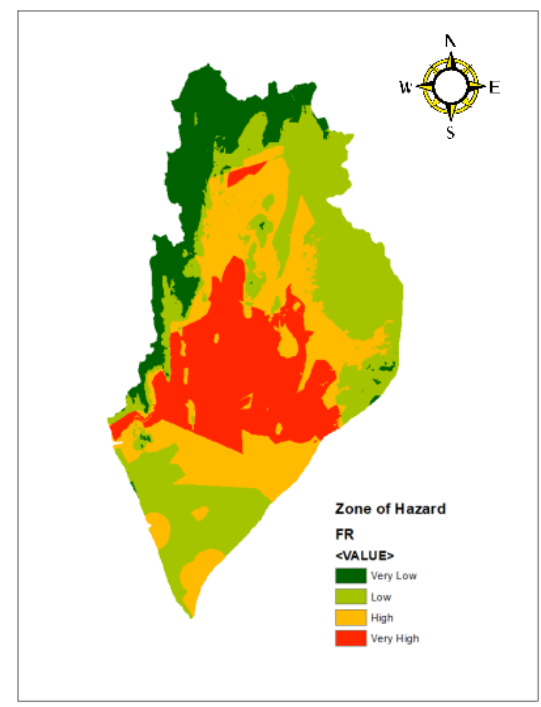

Fig. 4. Flood Hazard Mapping based on FR.

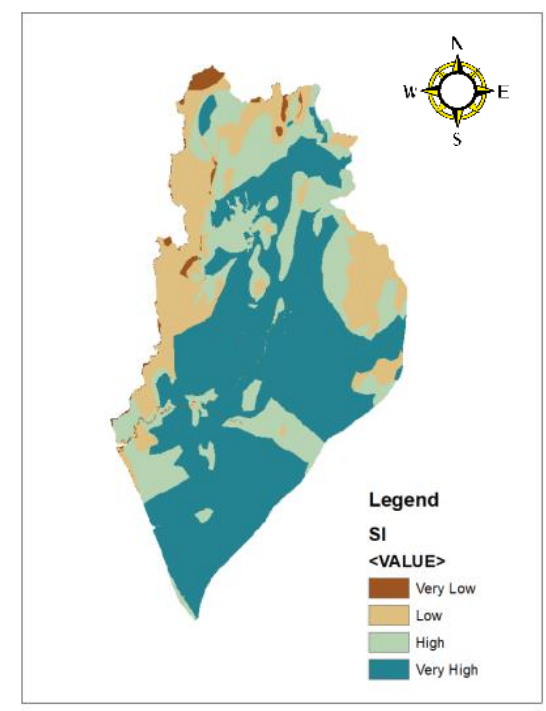

Fig. 5. Flood Hazard Mapping based on SI.

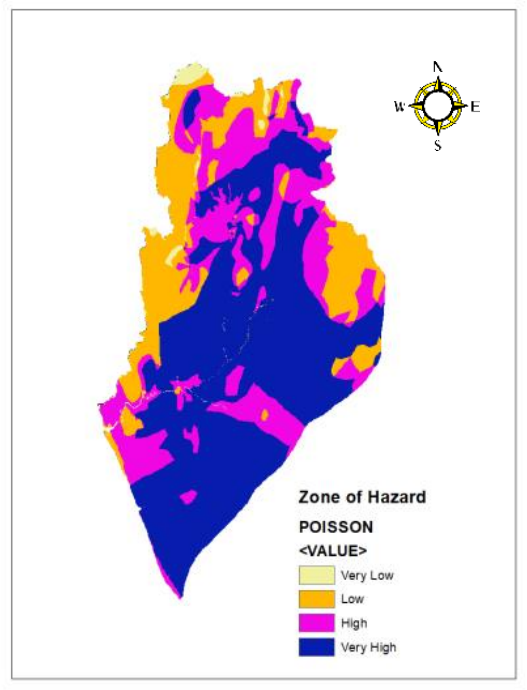

Fig. 6. Flood Hazard Mapping based on Poisson. 
In this study, the validation result for both frequency ratio and statistical index method had shown prediction accuracy of $86.96 \%$. However, statistical index is better method than frequency ratio because 18 point location in very high of hazard zone meanwhile frequency ratio is 16 location.

Table 2. The accuracy of three methods.

\begin{tabular}{|c|c|c|}
\hline Method & $\begin{array}{c}\text { Number of flood in high and } \\
\text { very high zone }\end{array}$ & $\begin{array}{c}\text { \% of flood in high and very high } \\
\text { zone }\end{array}$ \\
\hline Frequency Ratio & 20 & 86.96 \\
\hline Statistical Index & 20 & 86.96 \\
\hline Poisson Method & 12 & 52.17 \\
\hline
\end{tabular}

\section{Conclusions}

The comparison of three methods showed the statistical index method is best prediction accuracy in Flood Hazard Mapping. Therefore, the statistical method and frequency ratio in this study are valid for generalized planning and assessment purposes. Flood hazard mapping can be used as a great deal of importance for development of land. The findings of this study are intended to help all those involved in land use planning, development and management of land.

\section{References}

1. H. K. Hong, (2001)

2. N. W. Chan, 239-265 (2015)

3. Y. Hu, J. Huang, Y. Du, P. Han and W. Huang, Remote Sens. 7, 494-520 (2015)

4. M. S. Tehrany, B. Pradhan and M. N. Jebur, J. Hydrol. 504, 69-79 (2013)

5. L. T. K. Ho, M. Umitsu and Y. Yamaguchi, Remote Sens. Spat. Inf. Sci. 38, 275-80 (2010)

6. K. L. K. Wern, T. L. Tien and H. Lateh, IEEE Int. Conf. Imaging Syst. Tech. 273-8 (2011)

7. M. S. Tehrany, B. Pradhan, S. Mansor and N. Ahmad Catena. 125, 91-101 (2015)

8. P. Y. Julien, A. Ab. Ghani, N. A. Zakaria, R. Abdullah and C. K. Chang, J. Hydraul. Eng. 136, 251-61 (2010) 